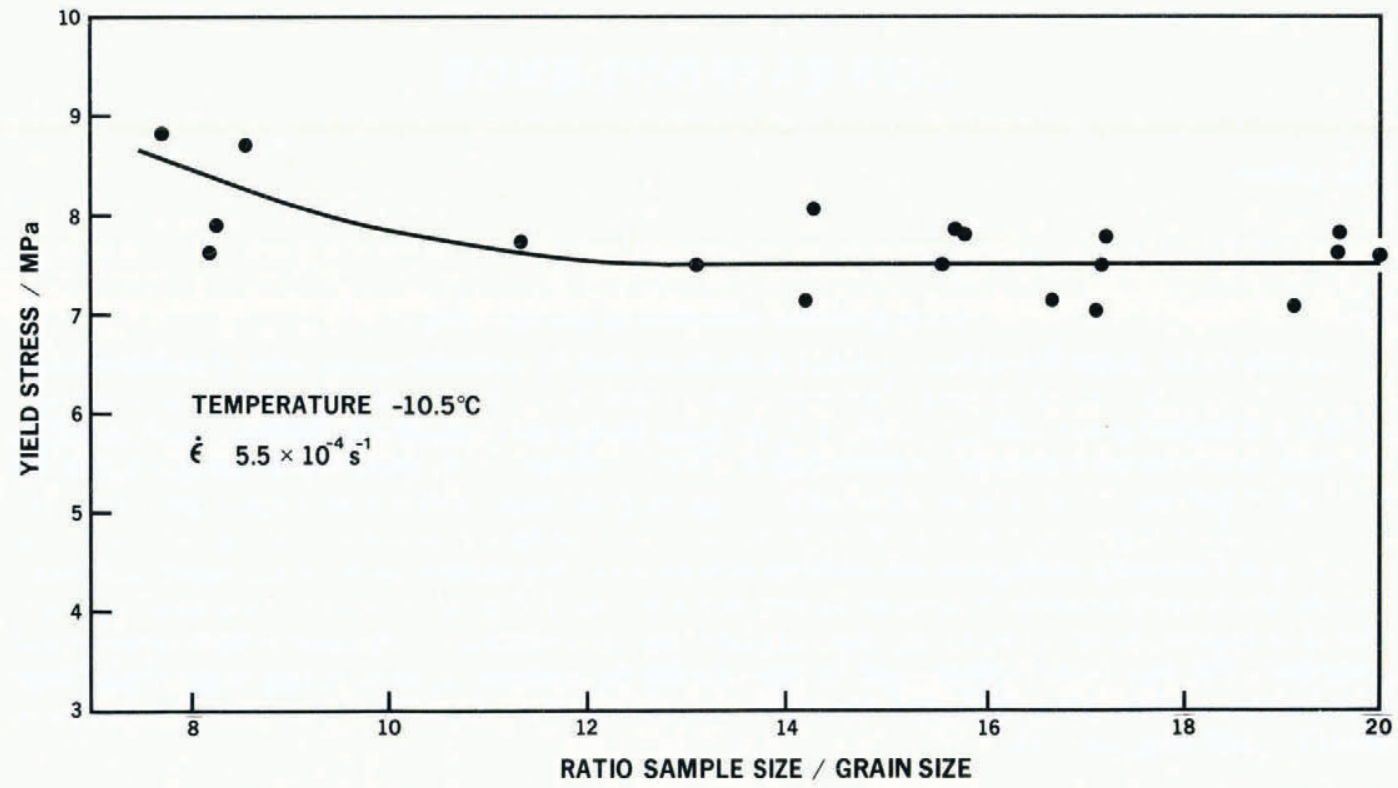

Fig. 2. The maximum yield stress plotted against the ratio of sample size to grain-size. The grain-size was kept constant at $1.0 \mathrm{~mm}$ and the sample diameter was varied. Below a ratio of 12 the yield stress depends on this ratio.

\title{
REFERENCES
}

Baker, R. W. 1978. The influence of ice-crystal size on creep. Fournal of Glaciology, Vol. 2 I, No. 85, p. 485-500. Duval, P., and Le Gac, H. 1980. Does the permanent creep-rate of polycrystalline ice increase with crystal size?

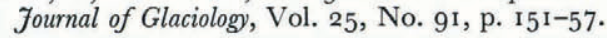

SiR, The weak underbelly of the West Antarctic ice sheet

Possible collapse of the West Antarctic ice sheet by surges of Thwaites and Pine Island Glaciers into the Pine Island Bay polynya of the Amundsen Sea was a subject addressed in papers by Lingle and Clark (1979) and Thomas (1979), and in abstracts by Denton and others (1979) and Hughes (1979), that were published in Vol. 24, No. 9o of the Journal of Glaciology. This concept was first developed in 1975 by George $\mathrm{H}$. Denton and me as part of our CLIMAP responsibilities to reconstruct the maximum Antarctic ice sheet and then to disintegrate the marine West Antarctic portion. Lingle and Clark (1979) have acknowledged us and CLIMAP in this regard, and we are grateful to them.

A brief history of the development of the concept that Pine Island Bay may be the weak underbelly of the West Antarctic ice sheet is in order, because the American Society for the Advancement of Science (AAAS) and the United States Department of Energy (DOE) sponsored a workshop at the University of Maine on 8-io April i98o to formulate a science plan that would "elucidate the research that might establish once and for all the likelihood and time frame of collapse of the grounded ice" in West Antarctica (David M. Burns, Director of the AAAS/DOE Climate Project, letter of 1 I October 1979).

CLIMAP (Climate: Long-range Investigations, Mapping, and Prediction) conducted two experiments, reconstructing the maximum ice-age climate 18 ooo years ago and the maximum interglaciation climate 125000 years ago. George H. Denton was the Principal Investigator responsible for providing the areas, elevations, and volumes of ice sheets as input boundary conditions for these two CLIMAP experiments. This work was done at the University of Maine, where I was the Task Group Leader responsible for numerically reconstructing and disintegrating ice sheets having areal extents specified by Denton. Results of this work are presented in chapter 6 (Hughes and others, 198I) and chapter 7 (Stuiver and others, 1981) of The last great ice sheets. 
In the CLIMAP proposal prepared in 1974, Denton and I outlined our plans to disintegrate the marine West Antarctic ice sheet for the CLIMAP maximum interglaciation experiment. While discussing this task in June 1975, Denton and I realized that the Amundsen Sea sector of the West Antarctic ice sheet was mostly drained by Thwaites Glacier and Pine Island Glacier (Fig. I), and that these two huge ice streams were not buttressed by a confined and pinned ice shelf. This realization focused our

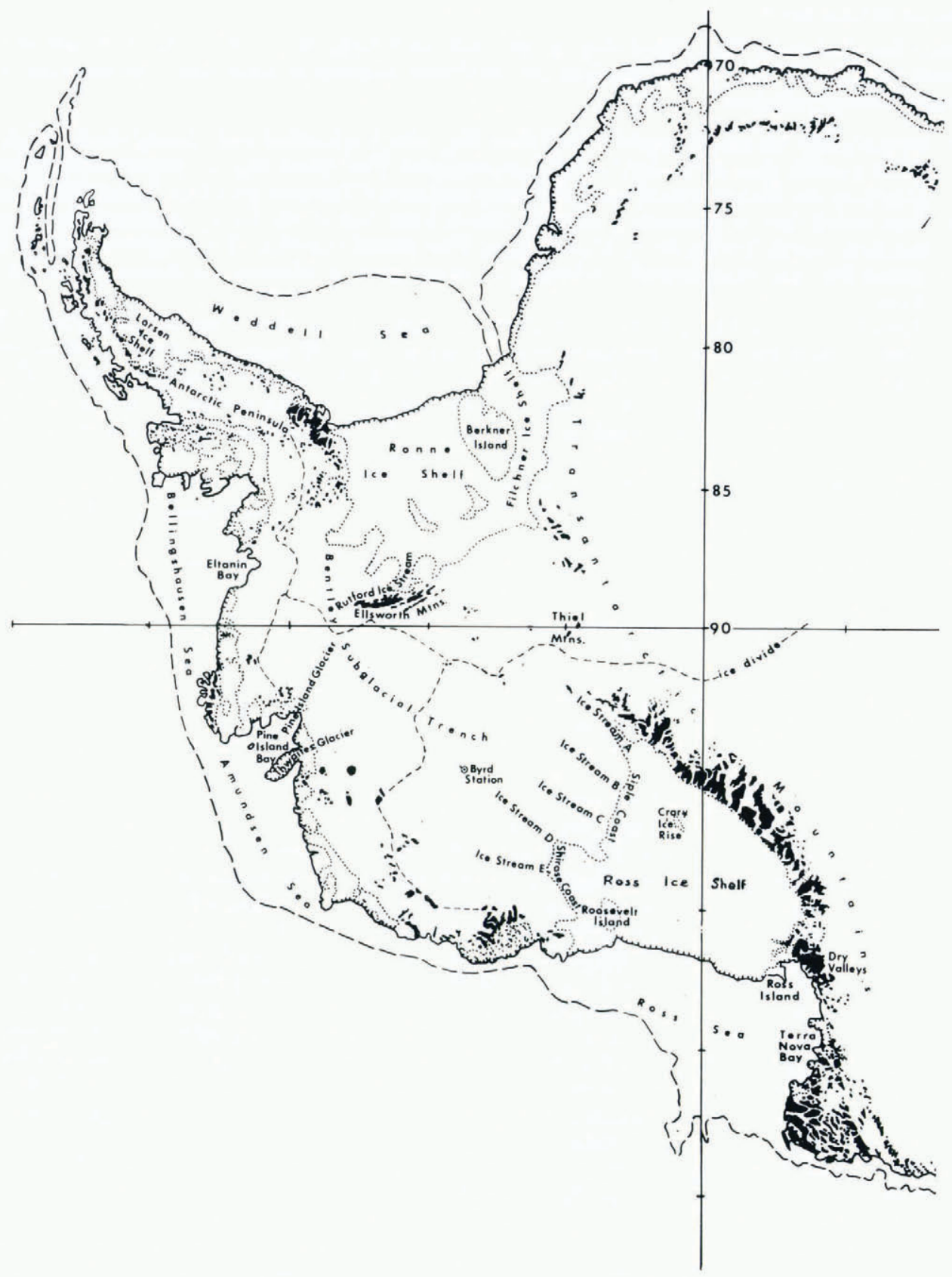

Fig. I. West Antarctica showing the position of Thwaites Glacier and Pine Island Glacier. 
attention on Pine Island Bay as the weak underbelly of the West Antarctic ice sheet, a concept which opened our eyes to what we think will be the mechanism for disintegration of the West Antarctic ice sheet during a proposed Super Interglaciation triggered by $\mathrm{CO}_{2}$-induced climatic warming (Stuiver and others, ig8r).

\section{POWER OF THE CONCEPT}

Once the concept of Pine Island Bay as the weak underbelly of the West Antarctic ice sheet is accepted, several seemingly unrelated facts can be drawn together to formulate a scenario for West Antarctic ice-sheet collapse.

I. Several small ice shelves border Pine Island Bay, which is studded with several small islands. It seems possible that an ice shelf could have occupied Pine Island Bay in the past and, by being pinned to the islands, would have effectively buttressed Thwaites and Pine Island Glaciers.

2. Pine Island Bay is presently a polynya that is kept free of sea ice by adiabatically warmed katabatic winds flowing down Thwaites and Pine Island Glaciers. If a former ice shelf in Pine Island Bay has disintegrated, reforming it under present climatic conditions would be unlikely.

3. Tricamera aerial photography and Landsat imagery show that Thwaites and Pine Island Glaciers have the heavily crevassed surfaces characteristic of glacial surges, these surfaces are summer ablation zones, and the ice-stream termini are floating in Pine Island Bay. The ice streams may have surged when a former buttressing ice shelf disintegrated, and retreat of the ice-stream grounding lines would be accelerated by the greatly magnified ice thinning rates that occur during the summer ablation of heavily crevassed ice.

4. Thwaites Glacier terminates as a huge floating ice tongue $200 \mathrm{~km}$ long. Floating ice tongues form when the ice-stream velocity exceeds the iceberg calving rate, which is most likely toward the beginning of a surge.

5. Pine Island Glacier terminates in a calving bay extending $30 \mathrm{~km}$ into the ice stream. Calving bays form when the iceberg calving rate exceeds the ice-stream velocity, which is most likely toward the end of a surge.

6. The ice divide of the West Antarctic ice sheet has a high saddle, I $800 \mathrm{~m}$ above sea-level, that separates the Thwaites Glacier ice drainage basin from the ice drainage basins of fast-moving ice streams D and E (Rose, i 979 ) that feed the Shirase Coast embayment of the Ross Ice Shelf. Through downdraw, a growing surge of Thwaites Glacier would create a saddle on the ice divide, but ice would not yet be downdrawn enough to lower the saddle and make it migrate toward the Ross Ice Shelf.

7. The ice divide of the West Antarctic ice sheet has a low saddle, only I $250 \mathrm{~m}$ above sea-level, that separates the Pine Island Glacier ice drainage basin from the ice drainage basin of slowmoving Rutford Ice Stream (Swithinbank, 1977) that feeds the Ellsworth Land embayment of the Ronne Ice Shelf. A declining surge of Pine Island Glacier would leave a low downdrawn saddle on the ice divide, which would have migrated toward the Ronne Ice Shelf and shrunk the ice drainage basin of Rutford Ice Stream, reducing its velocity.

8. Bentley Subglacial Trench averages I $500 \mathrm{~m}$ below sea-level and underlies the ice divide separating West Antarctic ice draining into Pine Island Bay from West Antarctic ice draining into the Ross and Ronne Ice Shelves. Surges of Thwaites and Pine Island Glaciers into the open water of Pine Island Bay will not only allow the Pine Island Bay grounding line to retreat into Bentley Subglacial Trench, through downdrawn retreat of the ice divide the surges will also shrink the ice drainage basins of ice streams feeding the Ross and Ronne Ice Shelves. This causes a negative shift in the mass balance of these ice shelves that would compel their grounding lines to also retreat into Bentley Subglacial Trench.

9. The Shirase Coast is a deep, and relatively recent embayment of the Ross Ice Shelf grounding line that probably resulted when Rockefeller Plateau ice was downdrawn into ice streams D and E (Lan'gway and others, I 974 ). These ice streams may be moving rapidly because they enter the unpinned northern sector of the Ross Ice Shelf, and retreat of the Shirase Coast grounding line would be accelerated if further collapse of Rockefeller Plateau ice was caused by a surge of Thwaites Glacier on the other side of the ice divide. 
I0. The West Antarctic ice sheet is less than $600 \mathrm{~km}$ wide between the Pine Island Bay and Ronne Ice Shelf grounding lines. A prolonged surge of Pine Island Glacier would cause both grounding lines to retreat; Pine Island Bay retreat occurs because downdraw is greatest for ice entering an unbuttressed ice stream, and Ronne Ice Shelf retreat occurs because downdrawn retreat of the ice divide has reduced the input from Rutford Ice Stream.

Linking these ten observations produces a scenario for disintegration of the West Antarctic ice sheet in which unstable stream-flow in Pine Island Bay downdraws the more stable sheet-flow in the interior and destabilizes metastable shelf-flow along the Ross and Weddell Sea margins.

\section{Preliminary test of the concept}

Our first test of the concept that Pine Island Bay is the weak underbelly of the West Antarctic ice sheet was made using the numerical model of ice-sheet disintegration that I developed in the summer of 1977 for the CLIMAP maximum interglaciation experiment (Stuiver and others, I98 I). Our CLIMAP ice-sheet disintegration model coupled a grounding-line retreat mechanism published by Thomas (1977) to theoretical ice-stream profiles I had derived for our CLIMAP ice-sheet reconstruction model. This allowed an ice stream surge to link grounding-line retreat to downdraw and retreat of the ice divide. Important variables controlling the surge were ice-ocean interactions related to rising sea-level, iceatmosphere interactions related to climatic warming, and ice-rock interactions related to basal melting and rebound beneath downdrawn ice.

James L. Fastook produced a computer solution for our CLIMAP model of ice-sheet disintegration and, during the fall of 1977 , applied the model to all the ice streams draining the maximum West Antarctic ice sheet that we reconstructed for the CLIMAP maximum glaciation experiment. That ice sheet was grounded to the edge of the West Antarctic continental shelf, which was taken as the $500 \mathrm{~m}$ bathymetry contour wherever the actual bathymetry was unmapped. The model reproduced the tenpoint scenario of West Antarctic collapse described above, provided that an ice shelf initially formed in Pine Island Bay but disintegrated about 100 years ago. Climatic warming after the Little Ice Age might have disintegrated the proposed ice shelf. Future collapse of the West Antarctic ice sheet resulted from present surges of Thwaites and Pine Island Glaciers and was complete in only 200 years. We showed our results to Robert $\mathrm{H}$. Thomas when he returned from Antarctica early in 1978. Thomas was skeptical because Pine Island Bay was one of the sectors having unmapped bathymetry. We assumed that the present-day grounding lines of Thwaites and Pine Island Glaciers were $500 \mathrm{~m}$ below sea-level.

Future collapse of West Antarctic ice into Pine Island Bay could be modelled more accurately if both the grounding line depth and the ice velocity across the grounding line were known for Thwaites and Pine Island Glaciers. I casually mentioned this to Robert J. Allen of the United States Geological Survey (USGS) in May 1978, when he was showing me aerial tricamera photographs of Byrd Glacier that I needed for my 1978-79 field study of the Byrd Glacier-Ross Ice Shelf interaction. Allen said that he had measured Thwaites Glacier velocities by triangulating moving crevasses located on 1947 tricamera photography and 1972 Landsat imagery. It now remained to measure the thickness and slope of Thwaites Glacier, especially at its grounding line, and to locate the grounding line. At the Ottawa Symposium on the Dynamics of Large Ice Masses in August 1978, I urged David J. Drewry to include these measurements in the NSF/SPRI/TUD radio echo-sounding program during the 1978-79 Antarctic summer. Drewry accomplished this, and he sent me the results in January 1980. By a fortunate coincidence, the Thwaites Glacier grounding line was close to $500 \mathrm{~m}$ below present-day sea-level.

I had told Robert H. Thomas about Robert J. Allen's velocity measurements for Thwaites Glacier and, when I returned from Antarctica in early 1979, I learned that Thomas had used them to calculate a critical ice thickness of $475 \mathrm{~m} \pm 75 \mathrm{~m}$ for irreversible retreat of the Thwaites Glacier grounding line (Thomas and others, 1979). I should add that, by USGS policy, Allen's data are available to anyone upon request.

\section{FUTURE WORK}

Now that the NSF/SPRI/TUD radio echo-sounding program has been discontinued, we must depend on the British Antarctic Survey (BAS) to measure the thickness and slope of Pine Island Glacier. This would be a natural extension of BAS radio echo-sounding over Rutford Ice Stream and vicinity (Swithinbank, 1977). In the meantime, encouraged by Robert J. Allen's work, David A. Tyler and I 
have requested I980 Landsat imagery of Thwaites and Pine Island Glaciers that we will compare with the 1972 imagery and photogrammetrically measure the surface velocity regimes of these two huge ice streams.

More and better field data will justify improvements in our CLIMAP ice-sheet disintegration model. The ability of an ice shelf to buttress ice streams can be modelled. In our model, the grounding line retreat rate of an ice stream having a floating terminus is

$$
v_{x}=\frac{\left(\rho \mathrm{w} / \rho_{\mathrm{I}}\right) v_{z}+(\alpha-\beta) u_{x}-\dot{a}-h_{\mathrm{I}} \dot{\epsilon}_{z z}}{\alpha-\beta\left(\mathrm{I}-\rho \mathrm{w} / \rho_{\mathrm{I}}\right)}
$$

where $\rho_{\mathrm{W}}$ and $\rho_{\mathrm{I}}$ are water and ice densities, $\alpha$ and $\beta$ are surface and bed slopes, $v_{z}$ is the rate of rising sea-level, $u_{x}$ is ice velocity, $\dot{a}$ is the net ice accumulation rate, $h_{\mathrm{I}}$ is ice thickness, and $\dot{\epsilon}_{z z}$ is the vertical creep-rate of ice, all measured at the grounding line (Stuiver and others, $198 \mathrm{I}$ ). When the ice stream is buttressed by an ice shelf

$$
\dot{\epsilon}_{z z}=-\frac{\psi}{A^{n}}\left[\frac{\rho_{\mathrm{I}} g h_{\mathrm{I}}}{2}\left(\mathrm{I}-\frac{\rho_{\mathrm{I}}}{\rho_{\mathrm{W}}}\right)-2 \tau_{\mathrm{S}}\left(\frac{s}{w}\right)-2 \sigma_{\mathrm{c}}\left(\frac{r}{w}\right)\right]^{n}
$$

where $\psi$ quantifies floating stream-flow diverging to become shelf-flow, $A$ and $n$ are the hardness coefficient and viscoplastic exponent in the creep law $\dot{\epsilon}_{z z}=\left(\sigma_{z z} / A\right)^{n}$ for ice, $g$ is gravity acceleration, $w$ is the width of the ice stream at the grounding line, $s$ is the length of the ice-stream flow-band from the grounding line to the calving front of the ice shelf, $r$ is the radius of an ice rise that pins the ice shelf in the flow-band originating from the ice stream, $\tau_{\mathrm{s}}$ is the lateral shear stress on the sides of this flow-band, and $\sigma_{\mathrm{c}}$ is the compressive stress at the ice rise. Part of the floating tongue of Thwaites Glacier has buckled laterally and seems to be rotating about a pinning point, in which case $\sigma_{\mathrm{c}}$ is important. The floating tongue of Pine Island Glacier is confined on both sides, in which case $\tau_{\mathrm{s}}$ is important. These are the buttressing stresses provided by a pinned and/or confined ice shelf, and they oppose the creep-spreading of floating ice specified by the first term in Equation (2). A photogrammetric determination of the surface velocity regimes of Thwaites and Pine Island Glaciers will permit these buttressing effects to be investigated in some detail.

We evaluated $u_{x}$ using our CLIMAP ice-sheet reconstruction model. In that model, the ice surface elevation above sea-level at $\Delta x \operatorname{step} i+\mathrm{I}$ measured from the ice-sheet margin along a surface flow line is

$$
h_{i+1}=h_{i}+\left[\tau_{0} /\left(h-h_{\mathrm{R}}\right)\right]_{i} \Delta x / \rho_{1} g
$$

where $h, h_{\mathrm{R}}$, and $\tau_{0}$ are the ice surface elevation, bed elevation, and basal shear stress at step $i, \Delta x$ is the step length, and $i$ is an integer. Taking $i=0$ at the calving front of an ice shelf, $\tau_{0}=0$ for all $\Delta x$ steps from the calving front to the grounding line and $\tau_{0}$ is determined from theory for all $\Delta x$ steps from the grounding line to the ice divide. Theoretical values of $\tau_{0}$ were derived across frozen and thawed beds, across melting and freezing beds, along ice streams and ice lobes, and from saddles to domes along ice divides (Hughes, 198I). Glacial geology and topography were used to identify these surface and bed conditions.

The value of $u_{x}$ in Equation ( $\mathrm{I}$ ) is obtained from the continuity equation:

$$
u_{x}=-\sum_{i}\left[\left(\dot{a}-u_{z}\right) w\right]_{i} \Delta x /\left(h-h_{\mathrm{R}}\right) w
$$

where $u_{z}$ is the vertical creep thinning rate, the summation is over all values of $\dot{a}, u_{z}$, and $w$ for each $\Delta x$ step from the grounding line to the ice divide, and $h, h_{\mathrm{R}}$, and $w$ in the denominator are measured at the grounding line. We evaluate $u_{z}$ for each step of grounding-line retreat by reconstructing surface flow-line profiles before and after the retreat step, using Equation (3), and then measuring the difference in $h$ between the profiles at each step. This surface lowering occurs in time $\Delta x / v_{x}$, where $v_{x}$ is given by Equation ( 1 ). An iterative computer solution is required. This surface lowering is downdraw resulting from grounding-line retreat. It causes the ice divide of the Thwaites and Pine Island Glacier drainage basins to retreat as their grounding lines retreat (Stuiver and others, $198 \mathrm{I}$ ).

Another source of surface lowering is downdraw resulting from the increasing length of an ice stream as it accelerates during a surge. Since ice streams have concave surface profiles, changes in their length can strongly influence $u_{z}$ in Equation (4). Length changes would be caused by changes in basal meltwater production that are proportional to changing rates of basal frictional heat generated during the 
surge. Since $u_{x}$ is almost entirely due to basal sliding in an ice stream, the rate of frictional heat production at the bed is $\left(u_{x} \tau_{0}\right)_{i}$, evaluated at each $\Delta x$ step $i$ along the ice stream. The change in length $\Delta I_{\mathrm{S}}$ of an ice stream due to a change in velocity $\Delta u_{x}$ in time $t=\Delta x / v_{x}$ is

$$
\Delta I_{\mathrm{S}}=\frac{2 h_{\mathrm{I}} \Delta u_{x} \Delta x^{2}}{\rho_{\mathrm{I}} H_{\mathrm{M}} \Lambda v_{x}} \sum\left(\tau_{\mathrm{o}} / h_{\mathrm{I}}\right)_{i}
$$

where $H_{\mathrm{M}}$ is the latent heat of melting (measured in energy units), the grounding line retreats one $\Delta x$ step in time $t, \Lambda$ is the thickness of the basal water layer at the grounding line, $h_{\mathrm{I}}$ and $u_{x}$ are ice thickness and velocity at the grounding line, and the summation is over values of $\tau_{0}$ and $h_{\mathrm{I}}$ along an ice stream of length $I_{\mathrm{S}}$ (Hughes, I98I ). Equation (5) expresses the enhanced downdraw that would occur during the early stage of surges of Thwaites and Pine Island Glaciers, when increasing $u_{x}$ causes these ice streams to lengthen.

The theoretical variation of $\tau_{0}$ along an ice stream of length $I_{\mathrm{S}}$ is

$$
\tau_{0}=k\left[\mathrm{I}-\frac{1}{2} f\left\{\mathrm{I}-\cos \left(\pi x / I_{\mathrm{S}}\right)\right\}\right]^{4 m /(2 m+\mathrm{I})} \tau_{\mathrm{M}}
$$

where $k$ quantifies sheet-flow converging to become stream-flow, $m$ is the viscoplastic exponent in the sliding law $u_{x}=\left(\tau_{0} / B\right)^{m}$ of glacial ice, $\tau_{\mathrm{M}}$ is the basal shear stress for sheet-flow over a thawed bed, $\tau_{0}=\tau_{\mathrm{M}}$ over the region $x \geqslant 2 I_{\mathrm{S}}$ of sheet-flow, $x=I_{\mathrm{S}}$ at the grounding line if a floating ice tongue forms, $x=0$ at the grounding line if a grounded ice lobe forms, $f=0$ for sheet-flow, $f=\mathrm{I}$ for streamflow, and $0<f<\mathrm{I}$ for lobate-flow at the ice margin (Hughes, 1981 I). Substituting Equation (6) into Equation (3) produces concave ice-stream profiles that can be fitted to Thwaites and Pine Island Glaciers, once their ice thicknesses and surface slopes are mapped by radio echo-sounding.

In our original CLIMAP ice-sheet reconstruction model, theoretical basal shear-stress variations $\tau_{F}$ and $\tau_{\mathrm{M}}$ for sheet-flow over frozen and thawed beds were calculated for ice sheets having an accumulation zone over their entire surface (Hughes, I98I). This is realistic for the ice-age and present-day Antarctic ice sheet, but climate warming during a Super Interglaciation might create an ablation zone over the ice-sheet surface along the margin. For a surface flow line of length $L$ from the margin to the ice divide, and having a surface equilibrium line at distance $E$ from the margin with average accumulation and ablation rates $a$ and $b$, mass conservation requires that:

$$
a(L-E)+b E=\mathcal{N}
$$

where $\mathcal{N}$ is the net positive or negative mass balance that would cause the ice sheet to thicken or thin. Define $B$ as the coefficient in the sliding law $u_{x}=\left(\tau_{0} / B\right)^{m}$ for glacial ice and $h_{\mathrm{E}}$ as ice surface elevation at the equilibrium line. When the ablation zone is over a frozen bed $(x \leqslant E)$,

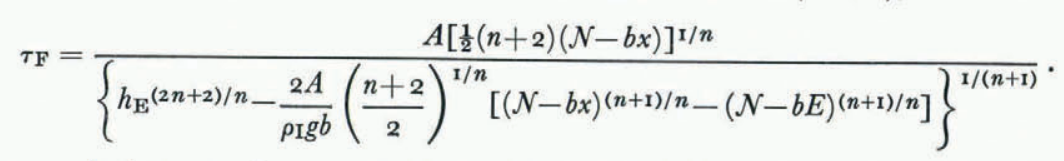

When the accumulation zone is over a frozen bed $(x \geqslant E)$,

$$
\tau_{\mathrm{F}}=\frac{A\left[\frac{1}{2}(n+2) a(L-x)\right]^{\mathrm{I} / n}}{\left\{h_{\mathrm{E}}^{(2 n+2) / n}-\frac{2 A}{\rho_{\mathrm{I}} g}\left[\left(\frac{n+2}{2}\right) a\right]^{\mathrm{I} / n}\left[(L-E)^{(n+1) / n}-(L-x)^{(n+\mathrm{I}) / n}\right]\right\}^{\mathrm{I} /(n+\mathrm{I})}} .
$$

When the ablation zone is over a thawed bed $(x \leqslant E)$,

$$
\tau_{\mathrm{M}}=\frac{B(\mathcal{N}-b x)^{\mathrm{I} / m}}{\left\{h_{\mathrm{E}}^{(2 m+\mathrm{I}) / m}-\left(\frac{2 m+\mathrm{I}}{m+\mathrm{I}}\right) \frac{B}{\rho_{\mathrm{I}} g}\left[(\mathcal{N}-b x)^{(m+\mathrm{I}) / m}-(\mathcal{N}-b E)^{(m+\mathrm{I}) / m}\right]\right\}^{\mathrm{I} /(2 m+1)}} .
$$

When the accumulation zone is over a thawed bed $(x \geqslant E)$,

$$
\tau_{\mathrm{M}}=\frac{B[a(L-x)]^{\mathrm{I} / m}}{\left\{h_{\mathrm{E}}^{(2 m+\mathrm{I}) / m}-\left(\frac{2 m+\mathrm{I}}{m+\mathrm{I}}\right) \frac{a^{\mathrm{I} / m} B}{\rho_{\mathrm{I}} g}\left[(L-E)^{(m+\mathrm{I}) / m}-(L-x)^{(m+\mathrm{I}) / m}\right]\right\}^{\mathrm{I} /(2 m+\mathrm{I})}} .
$$


Values of $h_{\mathrm{E}}$ over frozen and thawed beds are eliminated by setting $x=E$ and equating Equation (8) with Equation (9) and Equation (10) with Equation (II). Since $x=i \Delta x$ in the finite-difference scheme of Equation (3), these equations give changes in the position of the surface equilibrium line during retreat of the grounding line of an ice stream. Thwaites and Pine Island Glaciers have heavily crevassed summer ablation zones, so that the mean ablation rate $b$ in Equation (ro) is particularly high because heavy crevassing magnifies the ablating area. Using these equations for $\tau_{\mathbf{M}}$ to compute $\tau_{0}$ for ice streams in Equation (6) will be a substantial improvement in our CLIMAP ice-sheet reconstruction and disintegration models, linking ice-ocean to ice-atmosphere interactions.

Isostatic adjustments have also been improved in our CLIMAP ice-sheet reconstruction and disintegration models. Equation (3) can be used to obtain a best-fit match between computed and actual flow-line profiles of the West Antarctic ice sheet. However, if the ice sheet were removed and isostatic rebound were complete, the West Antarctic ice sheet could be reconstructed on the rebounded bed using the equation

$$
h_{i+1}=h_{i}+\left[\frac{\tau_{0}}{(\mathrm{I}+r)\left(h-h_{0}\right)-(\mathrm{I}+r)^{t}\left(h_{\mathrm{R}}{ }^{\prime}-h_{0}\right)}\right] \frac{\Delta x}{i}
$$

where $h_{0}$ is the elevation of the ice-sheet surface at the grounding line measured from the higher sea-level that exists after the ice sheet is gone, $h_{\mathrm{R}}{ }^{\prime}$ is the fully rebounded bed elevation at each step measured from this higher sea-level, and $r$ is the ratio of isostatic bed depression to ice elevation above the ice flotation line after the ice sheet re-forms and again depresses the bed. Comparing Equations (3) and (12) shows that

$$
h_{\mathrm{R}}=h-(\mathrm{I}+r)\left(h-h_{0}\right)+(\mathrm{I}+r) \mathbf{t}\left(h_{\mathrm{R}^{\prime}}-h_{0}\right) .
$$

Equation (12) constructs surface profiles that have been lowered by isostatic sinking of the bed under the ice sheet. In the original CLIMAP ice-sheet reconstruction model, ice-sheet profiles were constructed above the present-day undepressed bed using Equation (3), and then the bed was isostatically depressed at each $\Delta x$ step and a new surface profile was constructed (Hughes and others, 1981).

Balancing gravity forces for exponential isostatic rebound of bedrock having density $\rho_{\mathrm{R}}$ gives

$$
r=h^{\prime \prime} / h^{\prime}=r_{0} \exp \left(-t / t_{0}\right)
$$

where $r_{0}=\rho_{\mathrm{I}} /\left(\rho_{\mathrm{R}}-\rho_{\mathrm{I}}\right)$ for full isostatic equilibrium, $t_{0}$ is the time constant, ice thickness $h^{\prime}$ above the flotation elevation of marine ice isostatically depresses the bed an amount $h^{\prime \prime}$, full isostatic equilibrium before rebound gives $r=r_{0}$ at $t=0$, and full isostatic equilibrium after rebound gives $r=0$ at $t=\infty$. Equation (3) will reconstruct the present-day West Antarctic ice sheet over the present-day bed. Equation (12) will reconstruct the present-day West Antarctic ice sheet over the fully rebounded bed, provided that the present-day bed is in isostatic equilibrium. Since it is not, forcing profiles from Equations (3) and (12) to coincide will give the present-day non-equilibrium value of $r_{0}$ to be used in Equation (14) for $t=0$ at present.

Once a marine ice sheet is reconstructed at $t=0$ for a given value of $r_{0}$ using Equations (12) and (13) to compute surface and bed profiles along flow lines, collapse of the ice sheet and rebound of the bed can be computed from values of $r$ at $t>0$. Since a floating ice shelf may form beyond the retreating grounding line during collapse, it is necessary to keep the origin of coordinates $x, z$ at the initial ice-sheet calving margin, and to replace Equation (12) by:

$$
h_{i+1}=h_{i}+\frac{\left(\tau_{0} w+2 \tau_{\mathrm{s}} h\right)_{i} \Delta x}{\left[(\mathrm{I}+r)\left(h-h_{0}\right)-(\mathrm{I}+r) \mathbf{I}\left(h_{\mathrm{R}}^{\prime}-h_{0}\right)\right]_{i} \mathrm{I} g w-\tau_{\mathrm{s}} \Delta x}
$$

where $w$ is the width of the ice stream and, moving along the $x$-axis, $\tau_{0}=0$ for shelf-flow, $\tau_{0}$ increases up-stream and $\tau_{\mathrm{S}}$ decreases up-stream for stream-flow, and $\tau_{\mathrm{S}}=\mathrm{o}$ for sheet-flow (Hughes, 1981). Since $h \ll w$ in an ice stream, the $\tau_{\mathrm{s}}$ terms in Equation (15) are important only for a confined ice shelf. If the ice shelf is unconfined, $\tau_{\mathrm{s}}=0$ and ice-shelf thickness is constant except for mass-balance variations. After the ice-stream grounding line retreats one $\Delta x$ step in time $t_{\mathrm{I}}=\left(\Delta x / v_{x}\right)_{\mathrm{I}}$ due to changes in $v_{z}, u_{x}$, $\dot{a}$, or $\dot{\epsilon}_{z z}$ in Equation (I), a lowered surface profile is constructed from Equation (15) using $r$ computed for $t=t_{\mathrm{I}}$ in Equation (14). The partially rebounded bed is constructed from Equation (13), also using $r$ computed at time $t_{\mathrm{I}}$. After time $t_{2}=\left(\Delta x / v_{x}\right)_{\mathrm{I}}+\left(\Delta x / v_{x}\right)_{2}$ has elapsed, the grounding line has retreated a second $\Delta x$ step and caused further surface lowering and basal rebound. In general $v_{x}$ is different at 
$t_{1}$ and $t_{2}$. The new bed and surface profiles are constructed from Equations (13) and (15) using $r$ computed for $t=t_{2}$ in Equation (14). This procedure is repeated until grounding-line retreat has removed the marine ice sheet, or Equation (I) no longer allows the grounding line to retreat.

During and after collapse of a marine ice sheet, basal rebound continues beneath both grounded and floating ice until $r=0$ and $t=\infty$ in Equation (I4). This allows us to examine the possibility that new ice rises can form on an ice shelf wherever isostatic rebound re-pins the ice shelf to the bed. Such events would increase the ability of ice shelves to buttress ice streams, thereby slowing grounding-line retreat. This could be a factor if surges of Thwaites and Pine Island Glaciers cause further retreat of the Ross and Ronne Ice Shelf grounding lines.

I have examined the question of un-pinning versus re-pinning on the present-day Ross Ice Shelf, and have concluded from a stress analysis that un-pinning is more probable (Stuiver and others, $198 \mathrm{I}$ ). In this event, $\tau_{\mathrm{S}}$ is decreasing in Equation (15), and the Ross Sea sector of the West Antarctic ice sheet is becoming unbuttressed.

\section{Conclusions}

The concept that Pine Island Bay may be the weak underbelly of the West Antarctic ice sheet leads directly to a synthesis of field observations that permits a scenario of ice-sheet disintegration to be postulated. This scenario is duplicated by our preliminary CLIMAP ice-sheet disintegration model. New field data will justify improvements in the model which treat ice-ocean interactions at ice-stream grounding lines, ice-atmosphere interactions that influence the position of the surface equilibrium line, and ice-bed interactions that regulate ice-stream downdraw through basal melting and ice-shelf buttressing through isostatic rebound.

Department of Geological Sciences and Institute for Quaternary Studies, University of Maine at Orono, Orono, Maine 04469 , U.S.A. I September 1980 (revised 16 October 1980 )

T. J. Hughes

\section{REFERENCES}

Denton, G. H., and others. 1979. Reconstruction and disintegration of ice sheets for the CLIMAP I8 ooo and 125000 years B.P. experiments: results, by G. H. Denton, T. J. Hughes, J. L. Fastook, D. H. Schilling, and C. S. Lingle. Journal of Glaciology, Vol. 24, No. 9o, p. 495-96. [Abstract.]

Hughes, T. J. 1979. Reconstruction and disintegration of ice sheets for the CLIMAP 18 ooo and 125000 years B.P. experiments: theory. Fournal of Glaciology, Vol. 24, No. 90, p. 493-95. [Abstract.]

Hughes, T. J. I I81. Numerical reconstruction of paleo ice sheets. (In Denton, G. H., and Hughes, T. J., ed. The last great ice sheets. New York, Wiley-Interscience, p. 22 1-6i.)

Hughes, T. J., and others. I981. The last great ice sheets: a global view, by T. [J.] Hughes, G. H. Denton, B. G. Andersen, D. H. Schilling, J. L. Fastook, and C. S. Lingle. (In Denton, G. H., and Hughes, T. J., ed. The last great ice sheets. New York, Wiley-Interscience, p. 263-317.)

Langway, C. C., jr, and others. 1974. Chemical profile of the Ross Ice Shelf at Little America V, Antarctica, by C. C. Langway, Jr, M. [M.] Herron, and J. H. Cragin. U.S. Cold Regions Research and Engineering Laboratory. Research Report 316.

Lingle, C. S., and Clark, J. A. 1979. Antarctic ice-sheet volume at 18 ooo years B.P. and Holocene sea-level changes at the West Antarctic margin. Fournal of Glaciology, Vol. 24, No. 90, p. 213-30.

Rose, K. E. 1979. Characteristics of ice flow in Marie Byrd Land, Antarctica. Fournal of Glaciology, Vol. 24, No. 90 , p. $63-75$.

Stuiver, M., and others. I981. The history of the marine ice sheet in West Antarctica during the last glaciation: a working hypothesis, by M. Stuiver, G. H. Denton, T. [J.] Hughes, and J. L. Fastook. (In Denton, G. H., and Hughes, T. J., ed. The last great ice sheets. New York, Wiley-Interscience, p. 319-436.)

Swithinbank, C. W. M. 1977 . Glaciological research in the Antarctic Peninsula. Philosophical Transactions of the Royal Society of London, Ser. B, Vol. 279, No. 963, p. $161-83$.

Thomas, R. H. 1977. Calving-bay dynamics and ice-sheet retreat up the St. Lawrence valley system. Géographie Physique Quaternaire, Vol. 31, Nos. 3-4, p. 347-56.

Thomas, R. H. 1979. The dynamics of marine ice sheets. Fournal of Glaciology, Vol. 24, No. 90, p. $167-77$.

Thomas, R. H., and others. I979. Effect of climatic warming on the West Antarctic ice sheet, [by] R. H. Thomas, T. J. O. Sanderson, K. E. Rose. Nature, Vol. 277, No. 5695, p. 355-58. 